\title{
IDENTIFICATION OF GORGONIAN ISIS HIPPURIS (LINNAEUS 1758) POTENTIAL IN WATERS CONSERVATION AREA OF DAMPIER STRAIT RAJA AMPAT REGENCY OF INDONESIA
}

\author{
Arafat Gulam*, Fahlevi Arief Reza, Widyasari Ferliana \\ Sorong Division of Coastal and Marine Resources Management, \\ Ministry of Marine Affairs and Fisheries, Indonesia \\ *E-mail: gulam arafat@yahoo.com
}

\begin{abstract}
Gorgonacea is a group of soft corals spread in Indo-Pacific waters and some other places, especially tropical areas. Soft corals are the second biggest component after hard corals. Sea Bamboo or Isis hippuris are one of the types of soft corals set as limited protected biota. Waters Conservation Area of Dampier Strait is 1 out of 8 conservation areas in the Raja Ampat regency. The purpose of this study is to know the distribution of sea bamboo in the Waters Conservation Area of Dampier Strait Raja Ampat Regency, Indonesia. The result of identification shows that from 67 points there are 24 observation stations of coral reefs and only 13 stations are found for sea bamboo. Based on the results analysis, it is obtained a coverage percentage value of live coral is $43.47 \%$. This value is included in the medium category. Sea bamboo is recorded with the total colony as many as 581 colonies with the density value of 0.096 colony $/ \mathrm{m}^{2}$ or 968.33 colony/Ha. The distribution of discovered sea bamboo ranges in the depth of 3-7 meters.
\end{abstract}

\section{KEY WORDS}

Isis hippuris, waters conservation, rapid resources inventory, point intercept transects, belt transect.

The collection of live corals for marine aquarium trade has increased significantly in the past few years. This has raised the concern over the ecological implication of coral biological resources (Ferse et al., 2012). Morphotypes Isis hippuris is an ecological divergence and acts as the anthropogenic indicator that thrives on the mechanism of biodiversity and coral health in the Coral Triangle (Rowley, 2018).

Isis hippuris contains various compounds that can be used by the pharmaceutical and biochemical industries. The isolation of Isis hippuris produces hippuristanol which is a specific anti-viral substance with the ability to slow down and possibly prevent the process of viral replication (Manuputty, 2008). Isis hippuris contains a group of fatty acids, phenylacetonitrile, 1,2 benzenedicarboxylic, naphthalene and xylane, phenol-derived compound, hydrocarbon compound (Trianto et al., 2004), containing alkaloid, phenol, flavonoid and steroid compounds (Sayuti, Putri and Yunianta , 2016), containing Hippuristerone A compound, polyoxygenated steroids (Sheu et al., 2000), containing polyoxygenated steroids, J-L hippuristerones, E-F hippuristerones and gorgosteroids, $1 \alpha, 3 \beta$, $5 \beta$, 11a-tetrahydroxygorgostan-6- one (Chao et al., 2005). The extract has characteristics of cytotoxicity to carcinoma cells (Liang et al., 2010), the hippuris contains 2-butoxyethanol, hexanedioic acid (Sayuti, Putri, and Yunianta, 2017) containing Five novels (22R, 23S, 24S) -steroids, hippuristerones EI (Sheu et al., 2003)

Due to high market demand, the exploitation of Isis hippuris in some places is rather excessive and has damaged the ecosystem. In addition, Isis hippuris can be classified as endangered (Edrus and Suman, 2013). Limited protection will be carried across Indonesian waters within a period of 5 (five) years, with the exception of research and development (Kepmen KP Nomor 46/KEPMEN-KP/2014). The purpose of this research is to know the distribution of sea bamboo in Waters Conservation Area of Dampier Strait Raja Ampat Regency, Indonesia which is one of the habitats of Isis hippuris. 


\section{MATERIALS AND METHODS OF RESEARCH}

The research was conducted on October to November 2016 in the Waters Conservation Area of Dampier Strait Raja Ampat Regency, Indonesia. The research identified the potential of sea bamboo in the Waters Conservation Area of Dampier Strait Raja Ampat Regency. There were 67 observation points consisting of 43 observation points with RRI method and 24 observation stations of coral and sea bamboo.

One of the methods to identify the existence of Isis hippuris is using Rapid Resources Inventory namely snorkeling on the surface at a certain interval to determine the existence of Isis hippuris. The amount of discovered Isis hippuris is recorded based on its type (Wilkinson et al., 2003).

Point intercept transects (PIT) is used to determine the bottom waters coverage (English et al., 1997) to measure the object of bottom waters at the $50 \mathrm{~cm}$ interval under the 50 meters belt transect (100 points). Using the sufficient point they can give information comparable with LIT (Hill and Wilkinson, 2004).

Belt transect is similar to line transect but broader and often used to survey the specific impact on benthos such as bleaching or disease, or calculating the invertebrate(Hill and Wilkinson, 2004). Belt transect is used to calculate the number of the colony and measure the height as well as the width of the Isis hippuris colony with the transect length of 50 meters and the observation area of 5 meters ( 2.5 meters to the left and 2.5 to the right). For the analysis, comparison of the number of colonies is used to the area of belt transect observation.

\section{RESULTS AND DISCUSSION}

Based on the 24 observation stations of corals and sea bamboo, only 13 stations are discovered to have sea bamboo colony with a total colony of 581 colonies in the depth range of 3-7 meters. The division of the observations stations based on the area is as follows:

Table 1 - Distribution of observation stations by location

\begin{tabular}{|c|c|c|}
\hline No & Location & Station \\
\hline 1 & Waters of Salawati Island & $1-6$ \\
\hline 2 & Waters of Batanta Island & $7-13$ \\
\hline 3 & Waters of Mansuar Island & $14-16$ \\
\hline 4 & Waters of Gam Island & $17-24$ \\
\hline
\end{tabular}

The dominant substrate type is discovered between Acropora (AC) amounted to $24 \%$, Non-Acropora (NA) amounted to $19 \%$, the soft coral (SC) amounted to $10 \%$, and coral fragment (RB) amounted to $18 \%$. As for the algae species, Sponge (SP), dead coral (DC), dead corals with overgrown algae(DCA), and sand (Sand) and other species (OT) are also found but in small quantity. More details of information can be seen in Figure 2.

Based on the data of bottom waters coverage, it is obtained a percentage value of live corals coverage amounted to $43.47 \%$. This value is categorized as a medium. On some stations, it is discovered a low coral coverage, especially in the Salawati area. The highest coral coverage is discovered in the northern Salawati area, south of Batanta, Northern Batanta, and Northern Mansuar. This is supported by relatively protected waters condition and good current circulation. Thus, nutrient sources are abundant. For more details see Figure 3.

The lowest live coral coverage is discovered in station 4 namely waters of Jefman Island amounted to $8 \%$, and the highest is discovered in the station 8 namely waters around the Kasuari Island of South Batanta amounted to $87 \%$.

Sea bamboo is only discovered in 13 observation stations with the total colony amounted to 581 colonies with the density value of 0.096 colony $/ \mathrm{m}^{2}$ or 968.33 colony $/ \mathrm{Ha}$. The distribution of sea bamboo is discovered around the depth of 3-7 meters. The waters condition where sea bamboo was discovered tend to be an area with low speed of current 
and protected waters such as in the Wamega, North Batanta, Northern Mansuar, and South Gam areas.

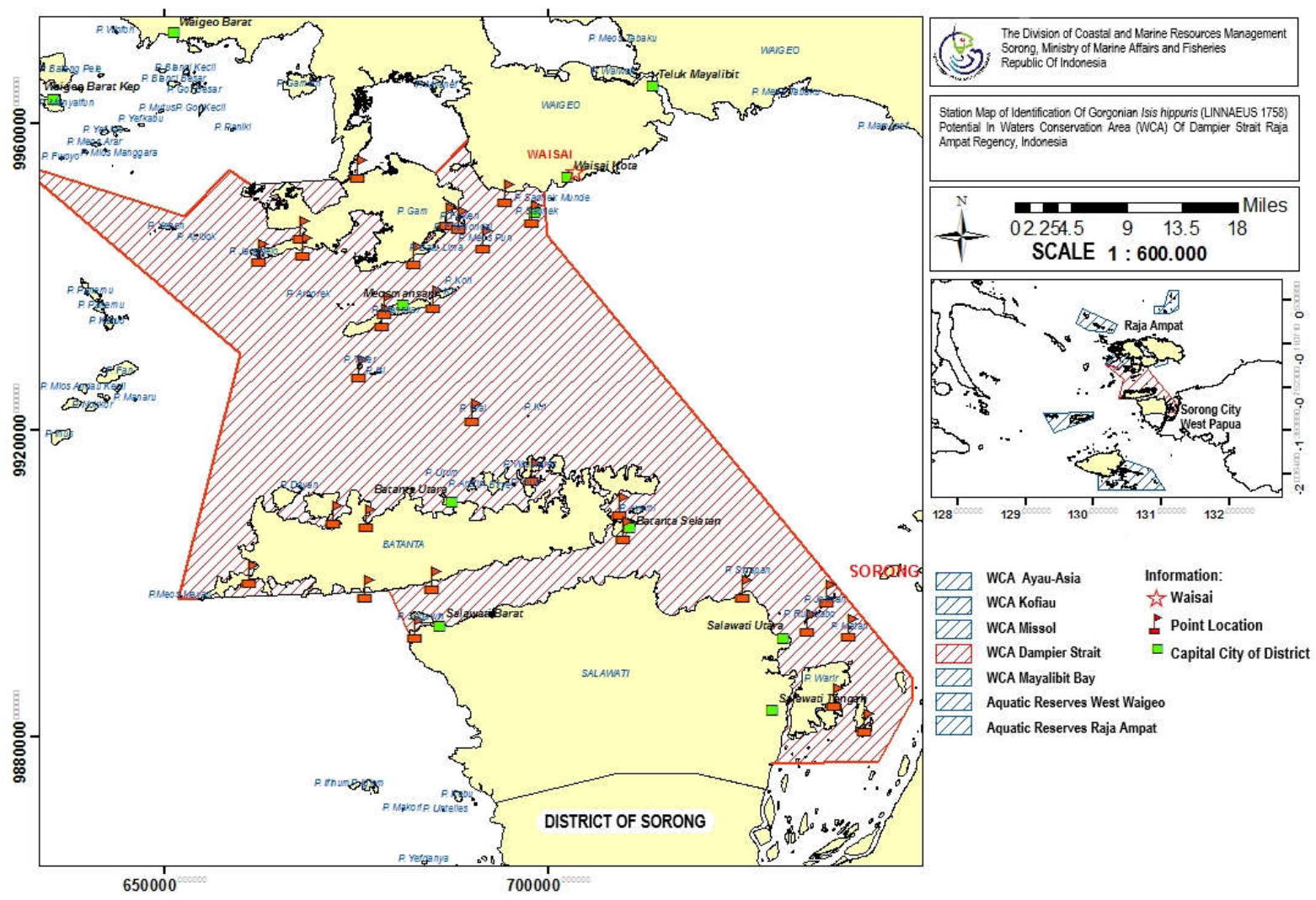

Figure 1 - Monitoring Station Map of Potency of Isis hippuris

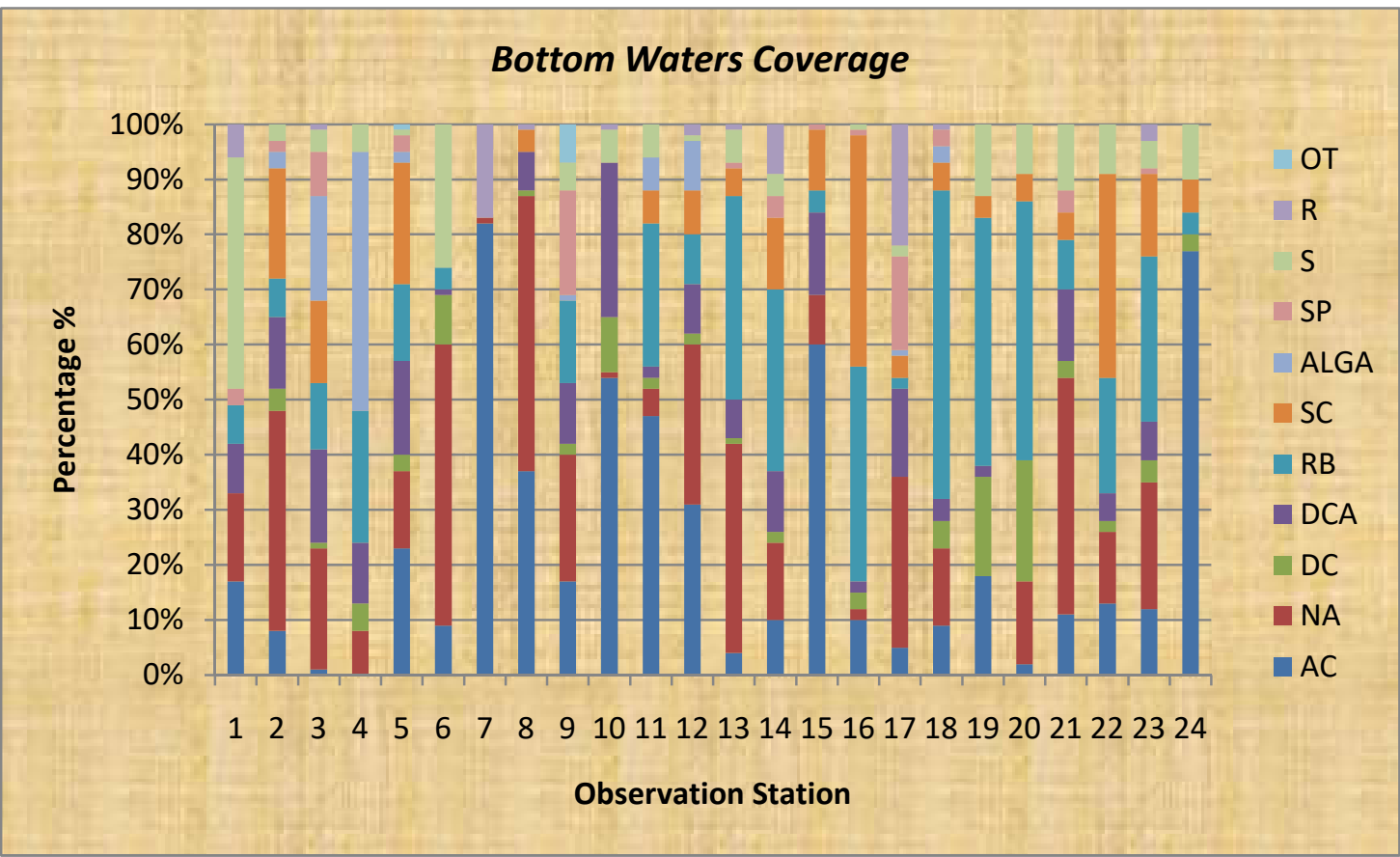

\begin{tabular}{|l|l|l|l|l|l|l|l|l|l|l|}
\hline AC & NA & DC & DCA & RB & SC & ALGA & SP & S & R & OT \\
\hline 24.22 & 19.25 & 4.25 & 8.63 & 18.54 & 10.32 & 3.79 & 2.79 & 7.08 & 2.78 & 0.33 \\
\hline
\end{tabular}

*in percents.

Figure 2 - Bottom Waters Coverage 
The largest number of sea bamboo colony is discovered in the Wamega and Warir Sapo area in the North Salwati district with the total of 263 colonies. Then, the second largest is in the Northern Mansuar area namely Yenbuba and Kurkapa with the total of 207 colonies. Meanwhile, the least number is discovered in North Batanta Area amounted to 16 colonies. For North Salawati and South Batanta areas, no colony of sea bamboo is found (Figure 4). This is possibly dues to the very strong and famous current condition in this Sagawin Strait area. Based on the data of current velocity measurement results, Sawagin Strait has the current velocity off $0.327 \mathrm{~m} / \mathrm{s}$. Based on the distribution of sea bamboo, it is found pattern criteria of grouping distribution (Mardianto, Nur, and Ramli, 2016).

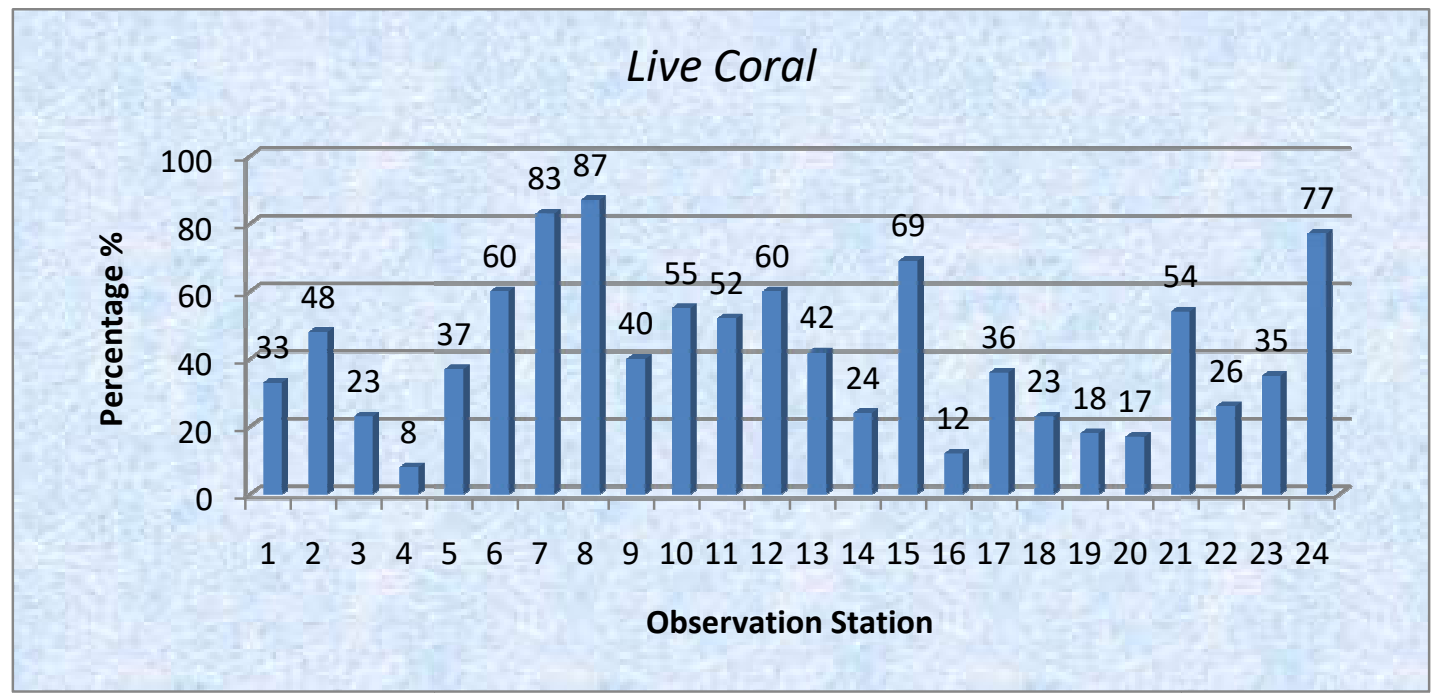

Figure 3 - Percentage of live corals by station

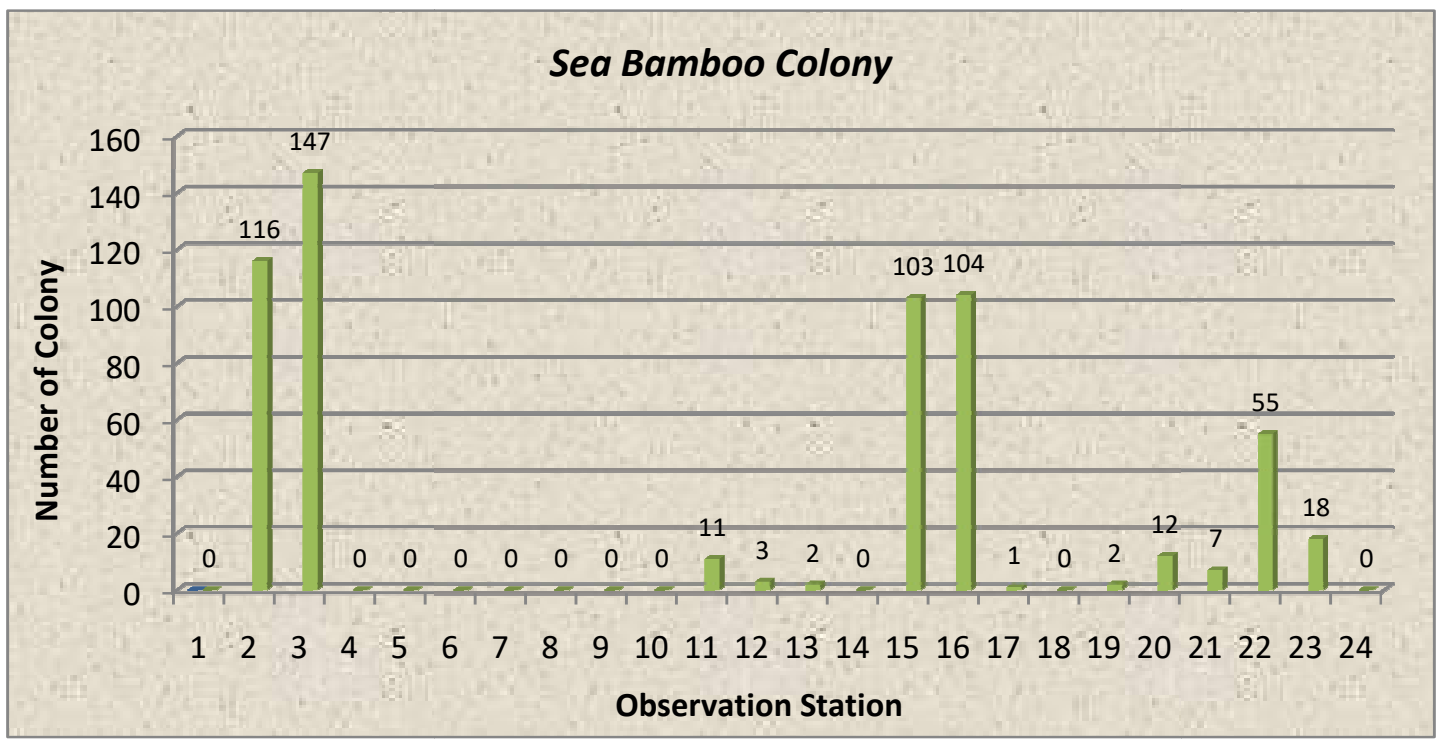

Figure 4 - The Number of Sea Bamboo Colony

The sea bamboo colony is measured by the height and width of the colony. The height of sea bamboo discovered in the Waters Conservation Area of Dampier Strait ranges from 5 $-104 \mathrm{~cm}$, while the width ranges from $2-110 \mathrm{~cm}$. the amount of distribution based on the height and width is presented in Figure 5.

The number of sea bamboo colony with height size range of $31-40 \mathrm{~cm}$ is discovered to be at most 139 colonies, whereas at least only 2 colonies in the $101-110 \mathrm{~cm}$ height range. The highest size found is discovered in waters of Warir Sapo, while the shortest is found in waters Wamega. 


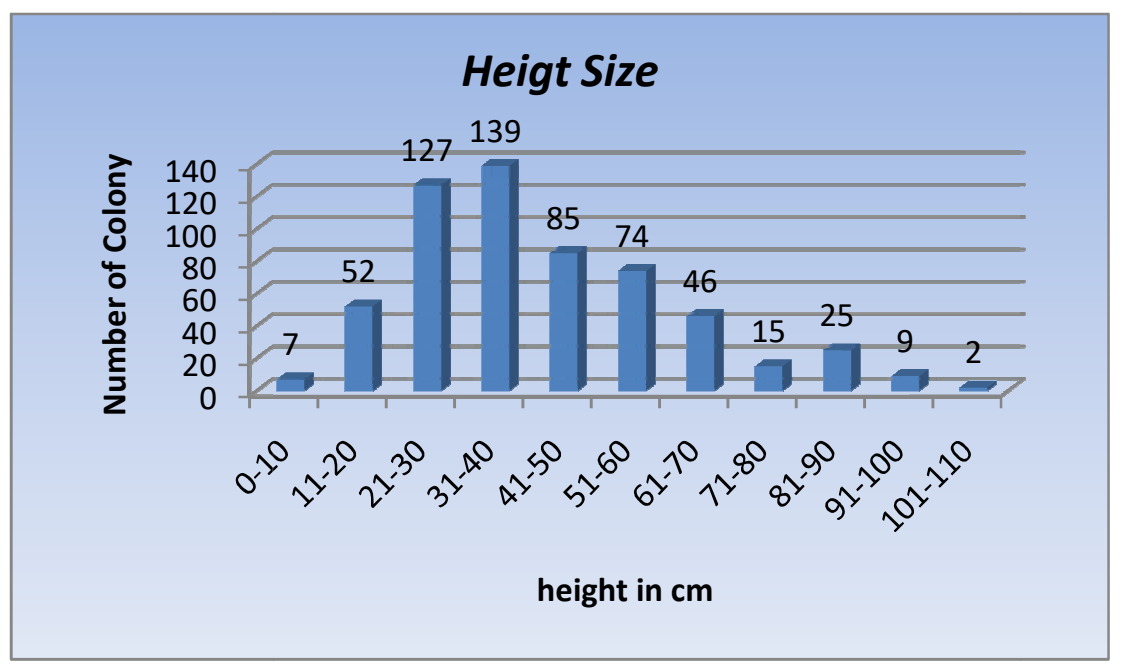

Figure 5 - Number of Sea bamboo Colony Based on Height Size

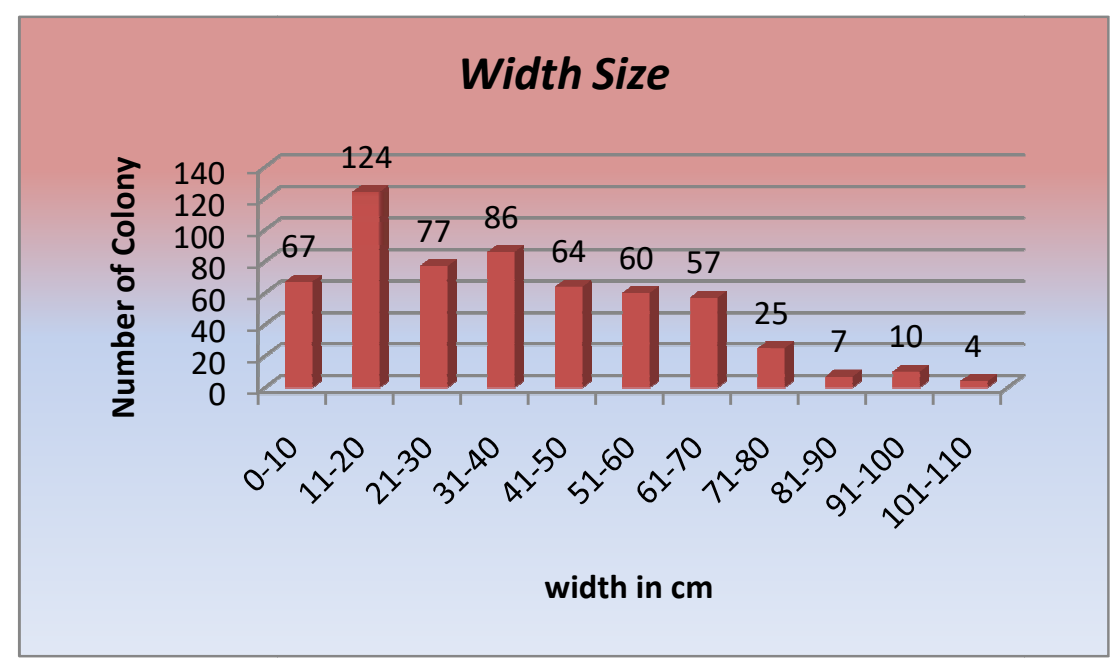

Figure 6 - The Number of Sea Bamboo Colony Based on Height and width

While based on the width, the largest number of sea bamboo colony is found in the range of $11-20 \mathrm{~cm}$ with the number of 124 colonies and the least is only 4 colonies in the width range of 101 to $110 \mathrm{~cm}$. The widest colony size is found in waters of Arevi, North Batanta, while the narrowest width is found in Wamega waters.

\section{CONCLUSION}

The condition of bottom waters coverage of Waters Conservation Area of Dampier Strait Raja Ampat is included in the medium category with the percentage of live coral coverage of $43.47 \%$. Meanwhile, the population density of sea bamboo is 0.096 colony $/ \mathrm{m}^{2}$ or 968.33 colony/Ha. The distribution of sea bamboo in the Waters Conservation Area of Dampier Strait does not spread evenly, which is only found in certain areas.

\section{REFERENCES}

1. Chao, C. H., Huang, L. F., Wu, S. L., Su, J. H., Huang, H. C. and Sheu, J. H. (2005) 'Steroids from the Gorgonian Isis hippuris', Journal of Natural Products, 68(9), pp. 13661370. doi: 10.1021/np050200u.

2. Edrus, N. I. and Suman, A. (2013) 'Kebijakan perlindungan dan konservasi hewan oktokoralian / bambu laut (Isis hippuris Linnaeus 1758)', Jurnal Kebijakan Perikanan Indonesia, 5(2), pp. 107-112. 
3. Ferse, S. C. A., Knittweis, L., Krause, G., Maddusila, A. and Glaser, M. (2012) 'Livelihoods of Ornamental Coral Fishermen in South Sulawesi/Indonesia: Implications for Management', Coastal Management, 40(5), pp. 525-555. doi: 10.1080/08920753.2012.694801.

4. Hill, J. and Wilkinson, C. (2004) 'Methods for ecological monitoring of coral reefs', Australian Institute of Marine Science, Townsville, p. 117. doi: 10.1017/CBO9781107415324.004.

5. Hodgson, G., Hill, J., Kiene, W., Maun, L., Mihaly, J., Liebeler, J., Shuman, C. and Torres, R. (2006) Reef Check Intruction Manual: A Guide Reef Check Coral Reef Monitoring. Reef Check Foundation, California, USA.

6. Kepmen KP Nomor 46/KEPMEN-KP/2014. Penetapan Status Perlindungan Terbatas Bambu Laut (Isis spp.).

7. Liang, C. H., Chou, T. H., Yang, C. C., Hung, W. J., Chang, L. C., Cheng, D. L. and Wang, G. H. (2010) 'Cytotoxic effect of Discosoma sp., Isis hippuris and Nephthea chabrolii on human oral SCC25 cells', Journal of the Taiwan Institute of Chemical Engineers. Taiwan Institute of Chemical Engineers, 41(3), pp. 333-337. doi: 10.1016/j.jtice.2009.09.006.

8. Manuputty, A. E. W. (2008) 'Isis hippuris Linnaeus 1758: Oktoral Pengahsil Antivirus', Oseana, XXXIII(1), pp. 19-24.

9. Mardianto, Nur, A. I. and Ramli, M. (2016) 'Studi ekologi bambu laut (Isis hippuris) di perairan Tanjung Tiram Kecamatan Moramo Utara Kabupaten Konawe Selatan [ The Study of Isis hippuris Ecology in Tanjung Tiram Waters North Moramo District', Jurnal Manajemen Sumber Daya Perairan, 1(3), pp. 323-332.

10. Rowley, S. J. (2018) 'Acclimatory capacity of the Gorgonian Isis hippuris Linnaeus, 1758 to environmental change in SE Sulawesi, Indonesia', Journal of Experimental Marine Biology and Ecology, 500(April 2017), pp. 73-88. doi: 10.1016/j.jembe.2017.12.012.

11. Sayuti, M., Putri, W. D. R. and Yunianta (2016) 'Phytochemicals Screening and Antioxidant Activity Test of Isis Hippuris Methanol Extract', International Journal of ChemTech Research, 9(07), pp. 427-434.

12. Sayuti, M., Putri, W. D. R. and Yunianta (2017) 'Antioxidant Activity and Identification of Compounds in the Extract of Sea Bamboo's (Isis Hippuris) Outer Layer', Research Journal of Pharmaceutical, Biological and Chemical Sciences, July-Augus(8(4)), pp. 884897.

13. Sheu, J. H., Chen, S. P., Sung, P. J., Chiang, M. Y. and Dai, C. F. (2000) 'Hippuristerone A, a novel polyoxygenated steroid from the gorgonian Isis hippuris', Tetrahedron Letters, 41(41), pp. 7885-7888. doi: 10.1016/S0040-4039(00)01348-4.

14. Sheu, J. H., Huang, L. F., Chen, S. P., Yang, Y. L., Sung, P. J., Wang, G. H., Su, J. H., Chao, C. H., Hu, W. P. and Wang, J. J. (2003) 'Hippuristerones E-I, new polyoxygenated steroids from the Gorgonian coral Isis hippuris', Journal of Natural Products, 66(7), pp. 917-921. doi: 10.1021/np020602r.

15. Trianto, A., Has, Y. Yan, Ambariyanto and Murwani, R. (2004) 'Uji Toksisitas Ekstrak Gorgonian Isis hippuris Terhadap Nauplius Artemia salina', Jurnal Ilmu Kelautan, 9(2).

16. Wilkinson, C., Green, A., Almany, J. and Dionne, S. (2003) Monitoring coral reef marine protected areas: version 1. IUCN Global Marine Program and Australian Institute of Marine Science. 